\title{
Pierre Avenas
}

with the collaboration of Minh-Thu Dinh-Audouin

Preface by Professor Jacques Livage

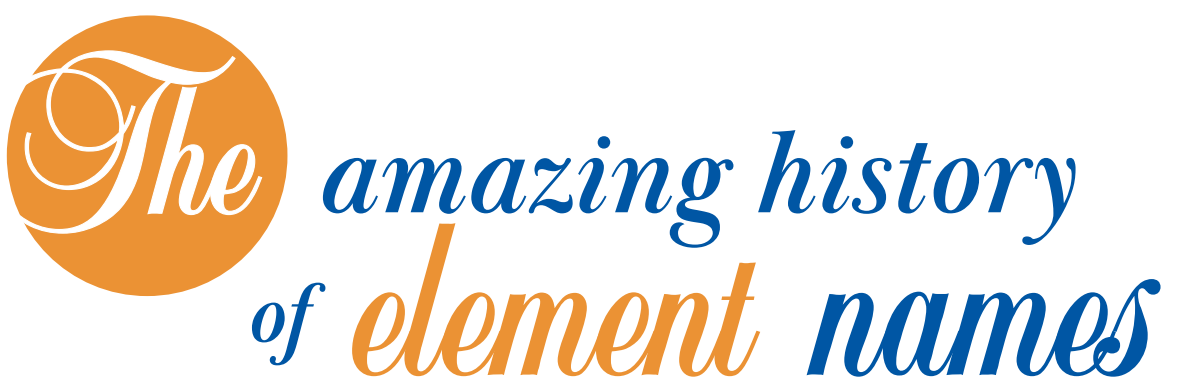

translated from La prodigieuse histoire du nom des éléments with the collaboration of Alan Rodney 


\section{By the same author}

\section{On polymers:}

- Mise en forme des polymères. Approche thermomécanique de la plasturgie, with J.-F. Agassant, J-Ph. Sergent, B. Vergnes and M. Vincent, Lavoisier, $4^{\text {th }}$ ed. 2014 ( $1^{\text {st }}$ ed.1982), preface by Pierre-Gilles De Gennes.

- Polymer processing. Principles and modeling, with J.-F. Agassant, P.-J. Carreau, B. Vergnes and M. Vincent, Hanser Publishers, $2^{\text {nd }}$ ed. 2017 ( $1^{\text {st }}$ ed. 1991).

- Etymology of main polysaccharide names, Chap. 2 of The European Polysaccharide Network of Excellence (EPNOE), Research initiatives and results, P. Navard (ed.), Springer, 2012.

\section{Etymology books:}

With Henriette Walter, published by Robert-Laffont:

- L'étonnante bistoire des noms des mammiferes. De la musaraigne étrusque à la baleine bleue, $2^{\text {nd }}$ ed. 2018 ( $1^{\text {st }}$ ed. 2003), republished in 2 vol., « Le goût des mots », Points: Chihuahua, zébu et Cie, 2007, and Bonobo, gazelle et Cie, 2008.

- La mystérieuse histoire du nom des oiseaux. Du minuscule roitelet à l'albatros géant, 2007.

- La fabuleuse histoire du nom des poissons. Du tout petit poisson-clown au très grand requin blanc, 2011.

- La majestueuse histoire du nom des arbres. Du modeste noisetier au séquoia géant, 2017.

With the collaboration of Minh-Thu Dinh-Audouin, published by EDP Sciences/SCF: - La prodigieuse bistoire du nom des éléments, 2018.

Design and layout: CB Defretin, Lisieux

Infography: Minh-Thu Dinh-Audouin

Printed in France

ISBN (print): 978-2-7598-2464-9

ISBN (ebook): 978-2-7598-2497-7

"La prodigieuse histoire du nom des éléments" was originally published in French in 2018 by EDP Sciences.

This work is subject to copyright. All rights are reserved, whether the whole or part of the material is concerned, specifically the rights of translation, reprinting, re-use of illustrations, recitation, broad-casting, reproduction on microfilms or in other ways, and storage in data bank. Duplication of this publication or parts thereof is only permitted under the provisions of the French Copyright law of March 11, 1957. Violations fall under the prosecution act of the French Copyright law. 
Ce n'est point en resserrant la sphère de la nature et en la renfermant dans un cercle étroit qu'on pourra la connaître ; ce n'est point en la faisant agir par des vues particulières qu'on saura la juger ni qu'on pourra la deviner ; ce n'est point en lui prêtant nos idées qu'on approfondira les desseins de son auteur. Au lieu de resserrer les limites de sa puissance, il faudra les reculer, les étendre jusque dans l'immensité ; il ne faut rien voir d'impossible, s'attendre à tout, et supposer que tout ce qui peut être, est.

Buffon, Histoire naturelle

It is not by tightening the sphere of nature and enclosing it in a narrow circle that we will be able to know it; it is not by making it act by particular views that we will be able to judge it nor guess it; it is not by lending it our own ideas that we will be able to deepen the designs of its author. Instead of tightening the limits of its power, we must push them back, extending them into the immensity; we must not see anything as impossible, we must expect everything, and suppose that everything that can be, is.

Buffon, Histoire naturelle 


\section{Preface}

\section{THE AMAZING HISTORY OF ELEMENT NAMES}

Year 2019 was declared as the International Year of the Periodic Table of the Chemical Elements by UNESCO. It was indeed 150 years ago that Mendeleev published his famous Periodic Table bringing together the 63 chemical elements already known at that time. The 118 elements known today perfectly fit together, including the empty spaces left by Mendeleev. It was therefore useful to recall the history of this table and the origin of the names of the chemical elements. This is what Pierre Avenas has done, already well-known for the etymological articles he published in L'Actualite Chimique, the journal of the French Chemical Society. A priori, such an opus could have been a simple enumeration of the elements classified according to their alphabetical order or by the date of their discovery. But actually this book, based as it is on the etymological origin of the names, takes us through a real odyssey of mineral, living and even thinking matter. He shows us how the whole history of Humanity lies behind the simple denomination of the chemical elements, from the four elements of Empedocles to the recently discovered radioactive elements. Moreover, the term element does not apply only to the atoms of the Periodic Table. It also applies to the molecules that build living matter. The names of the chemical elements come from very diverse origins. They most often do not come from the simple field of chemistry and are inspired by other scientific or cultural fields.

The Periodic Table of elements reveals Mendeleev's genius. It is undoubtedly one of the most beautiful manifestations of the human spirit. At that time, only 63 elements were known, characterized by their mass and chemical properties. Atoms, each with its nucleus and electronic layers, had not yet been discovered by Niels Bohr. How was it then possible to classify the known chemical elements, leaving empty spaces for those which would be discovered later? 
The book naturally starts with the four elements suggested by Empedocles (fire, air, water and earth) on which the description of matter was based until the $18^{\text {th }}$ century. It reminds us of the basic role of metals in the history of mankind, from the Bronze Age to the Iron Age! The book then takes us to other horizons, such as mythology, history or geography. It shows us which people, beliefs or circumstances inspired the name of each element. We thus cover the entire history of mankind, from the pigments used in parietal wall paintings to very recently discovered radioactive elements. The elements, which in fact constitute all the living and inanimate matter of the Universe, play a basic role in our history. Far beyond simple chemistry, Pierre Avenas opens up a vast horizon in which sciences, history and humanities are closely intertwined.

Jacques Livage

Professor at the Collège de France Member of the French Académie des Sciences 


\section{Foreword}

\section{THE AMAZING HISTORY OF ELEMENT NAMES}

Year 2019 was proclaimed by UNESCO the

"International Year of the Periodic Table of Chemical Elements".

This theme is more familiar than it sounds in scientific terms, since we use the names of chemical elements every day, such as the oxygen we breathe or the helium we use to inflate balloons. Gold and silver are also chemical elements, as are copper or iron and numerous other metals. Some elements are known to be beneficial to health, such as phosphorus for the brain functions, fluorine for our teeth, sulphur for our hair... and others are known as trace elements, such as iodine or selenium. And everyone knows that table salt is sodium chloride, where two elements, chlorine and sodium, combine. Finally, let's mention the field of energy, where we are constantly talking about carbon, but also photovoltaic silicon and uranium as used in nuclear power plants. We can see that a great many chemical elements are no strangers to us.

Today, 118 of them have been identified, 90 of which are natural on Earth, where they make up the totality of matter, i.e., including the mineral or living kingdoms. The elements combine in the countless substances and compounds that surround us, many of which are part of daily life.

\section{- An approach based on etymology...}

This book is a collection of articles, known as "clins d'œil étymologiques" ("etymological winks"), published since 2012 in L'Actualité Chimique, a journal of the Société Chimique de France $\left(\mathrm{SCF}^{1}\right)$, French Chemical Society. The basic, underlying idea is to present the etymological

1. www.societechimiquedefrance.fr 
origin of the names of substances, whether they be chemical elements or compounds such as starch, brass or plexiglas.

But that's not all, the aim of the book goes far beyond that.

\section{-... and that leads to worlds that are sometimes unsuspected}

Indeed, the etymology of a name often tells us a great deal about the discovery of the substance evoked, about the research scientists involved, and even about the state of science at the time of discovery. A whole history that quickly led us on to other scientific or cultural fields such as botany and zoology, astronomy, history and mythology, medicine and biology, technology and industry...

Names that make people travel, if only because they are given in English, French and often in Spanish and German. Both the chapter titles and the illustrations give free rein to the reader's imagination.

But the aim of the book is also to make the Periodic Table more familiar, as highlighted in the theme of the year 2019.

\section{- From the list of elements to the Periodic Table}

In 1789, Lavoisier established the concept of the chemical element and his Traité élémentaire de chimie listed 23 elements known at that time.

Later on, other elements were discovered, classified by mass from the lightest, hydrogen, to the heaviest, uranium. And, taking into account their properties, they were arranged in a table with several columns.

And it was a graduate from the French engineering school École Polytechnique, Alexandre de Chancourtois (1820-1886), who was the first to introduce periodicity in this classification, in 1862, in the original form of a helix traced on a cylinder, the so-called Telluric screw still visible at the École des Mines de Paris. Then, in the following few years, other researchers, a priori independently of each other, presented this periodicity in a double-entry table. This was notably the case in Germany by Lothar Meyer and in Russia by Dmitri Mendeleev, who first used this table as a predictive tool. 


\section{- Mendeleev's table, which is certainly periodic and} above all predictive

Mendeleev (1834-1907), professor of chemistry at the Institute of Technology and at the University of St. Petersburg, Russia, marked the history of chemistry with his publication in $1869^{2}$, not so much by the concept of periodicity of the elements, already well understood by others, but above all by predicting the subsequent discovery of missing elements in slots that remained empty in his table of the 63 elements known at that time. He also predicted certain properties of these future elements, several of which were actually discovered during his lifetime, which caused a real sensation.

These historical elements can be found in The amazing history of element names and many other references to the Periodic Table, the construction of which can be followed throughout the book.

But for the Ancient scholars, the elements were fire, air, water and earth, offering an excellent place to start Chapter 1.

2. E. Scerri, Le tableau périodique, Son histoire et sa signification, EDP Sciences, Paris, 2011, 349 pp, p. 64 ( $1^{\text {st }} \mathrm{ed}$. The Periodic Table, its story and its significance, Oxford, 2006). 


\section{To make the reading easier}

\section{- Typographical conventions}

in italics

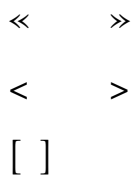

the word itself

the meaning of the word

graphical form

pronunciation

*(in front of a word) reconstructed form, non-attested in writing With a few exceptions, Greek words are transliterated according to the usual standards:

$\alpha \rightarrow \mathrm{a} \quad \beta \rightarrow \mathrm{b} \quad \eta \rightarrow \hat{\mathrm{e}} \quad \theta \rightarrow$ th $\quad \varphi \rightarrow$ ph $\quad \psi \rightarrow$ ps $\quad \omega \rightarrow \hat{\mathrm{o}}$ $\chi \rightarrow \mathrm{kh}$ (becomes $<\mathrm{ch}>$ pronounced $[\mathrm{k}]$, in Latin and in English, French...),

$v \rightarrow \mathrm{u}$ (becomes $<\mathrm{y}>$ in Latin and in English, French...)

Example :

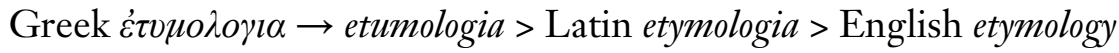

Words written in specific alphabets (Cyrillic, Arabic...) are also transliterated

\section{- Some keywords}

- Indo-European: refers to a reconstructed language, believed to have been spoken 5000 years before our era in a region near the Black Sea, and from which the languages of the so-called Indo-European family originate, consisting mainly of Sanskrit, Asian languages (Persian, Hindi...), and most European languages: Greek, Latin and the Romance languages from which they come (Italian, Spanish, French...), Slavic languages (Russian...), Germanic languages (English, German...), Celtic languages (Breton...)... 
- atom: from the Greek atomos, 'indivisible', already describing an indivisible particle in Democritus or Aristotle. It was around 1900 that the structure of the atom was understood: a positive nucleus surrounded by negative electrons. Since then, as in this book, we can say chemical elements as well as atoms.

- ion: an atom that has either captured one or more electrons (viz., an anion, negative) or has lost one or more electrons (viz., a cation, positive). First coined by the English physicist Faraday in 1834, this word comes from the Greek ion, a present participle of the verb "to go", therefore "going, that goes", either towards the anode (the + pole), or towards the cathode (the - pole).

- isotope: from the Greek iso, "the same", and topos, "place", created in 1913 by the English physicist Soddy to designate atoms in the same slot of the Periodic Table, i.e., sharing the same atomic number (same number of electrons) but different masses. Example: for carbon (atomic number 6) we know carbon 14 , which is a radioactive isotope, whereas the most common isotope, carbon 12 , is not.

\section{- IUPAC (International Union of Pure and Applied Chemistry)}

The International Union of Pure and Applied Chemistry is a non-governmental organization based in Zurich. Founded in 1919, it is interested in the progress of chemistry, physical chemistry, biochemistry, etc. Its members are $\mathrm{n}$ ational chemical societies. It is IUPAC that validates the chemical nomenclature, including the names of chemical elements (or atoms), their chemical symbols, isotopes, etc. Example: IUPAC recently (June 8, 2016) validated the name of the latest element identified to date, oganesson $(\mathrm{Og})$, atomic number 118.

Depending upon the context, the same molecule can be represented by different sorts of formulae or drawings. Example of propane:

$$
\mathrm{C}_{3} \mathrm{H}_{8} \quad \mathrm{CH}_{3} \mathrm{CH}_{2} \mathrm{CH}_{3} \quad \mathrm{CH}_{3}-\mathrm{CH}_{2}-\mathrm{CH}_{3}
$$
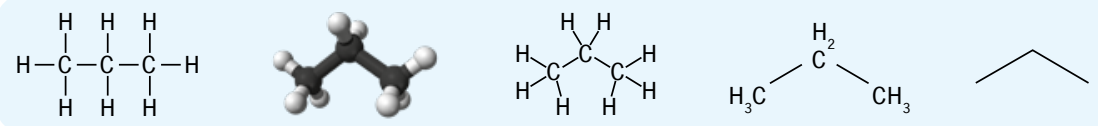